Portland State University

PDXScholar

Urban Studies and Planning Faculty

Nohad A. Toulan School of Urban Studies and

Publications and Presentations

Planning

2010

\title{
The Winners in China's Urban Housing Reform
}

John R. Logan

Brown University

Yiping Fang

Portland State University, yfang@pdx.edu

Zhanxin Zhang

Chinese Academy of Social Sciences

Follow this and additional works at: https://pdxscholar.library.pdx.edu/usp_fac

Part of the Public Policy Commons, Urban Studies Commons, and the Urban Studies and Planning Commons

Let us know how access to this document benefits you.

\section{Citation Details}

Logan, John R.; Fang, Yiping; and Zhang, Zhanxin, "The Winners in China's Urban Housing Reform" (2010). Urban Studies and Planning Faculty Publications and Presentations. 144.

https://pdxscholar.library.pdx.edu/usp_fac/144

This Post-Print is brought to you for free and open access. It has been accepted for inclusion in Urban Studies and Planning Faculty Publications and Presentations by an authorized administrator of PDXScholar. Please contact us if we can make this document more accessible: pdxscholar@pdx.edu. 


\title{
The Winners in China's Urban Housing Reform
}

\author{
John R. Logan*, Yiping Fang ${ }^{* *}$, and Zhanxin Zhang ${ }^{\dagger}$ \\ *Brown University, Sociology, Providence, USA **IHS, Erasmus University, Rotterdam, The \\ Netherlands ${ }^{\dagger}$ Chinese Academy of Social Science, Beijing, China
}

\section{Abstract}

Housing reform in China has proceeded on two tracks: privatization of public housing and development of a new private housing sector. During this period of transition, rents have remained relatively low in the remaining public housing, and purchase prices offered to occupants of public housing have been well below market prices. Although these rents and prices are partly based on known formulas, there is considerable variability in how much people pay for similar apartments. This study uses 2000 Census data to estimate the housing subsidy received by the remaining renters in the public sector and purchasers of public housing, based on private sector prices for housing of comparable quality and size. The paper also analyzes variation in the estimated discount from market prices that these people receive. The findings show that the biggest winners in China's transition from socialist housing allocation are those who were favored in the previous system, based on such factors as residence status, education and occupation.

\section{Keywords}

Comparative housing; housing privatization; housing tenure; China

\section{Introduction}

In the early 1980s the Chinese Government announced that the national policy of economic reform would be extended to the housing sector, first by raising public housing rents to market prices and then by privatizing housing production and consumption. These changes would radically change a system in which most urban residents relied on their work units or on municipal housing authorities to provide shelter at highly subsidized rents (Logan et al., 1999). Indeed, an apartment allocated by a person's employer was almost free, but it was also likely to be small, poorly equipped and hard to obtain. Reform could require people to pay more for housing (compensated only partly by rising wage levels), but it could also spur investment in a housing stock that had fallen far behind people's needs (Kosareva \& Struyk,

\footnotetext{
(C) 2010 Taylor \& Francis

Correspondence Address: John R. Logan, Brown University, Sociology, Box 1916, Brown University, Providence 02912, USA. john_logan@brown.edu.

Publisher's Disclaimer: Full terms and conditions of use: http://www.tandfonline.com/page/terms-and-conditions

This article may be used for research, teaching, and private study purposes. Any substantial or systematic reproduction, redistribution, reselling, loan, sub-licensing, systematic supply, or distribution in any form to anyone is expressly forbidden.

The publisher does not give any warranty express or implied or make any representation that the contents will be complete or accurate or up to date. The accuracy of any instructions, formulae, and drug doses should be independently verified with primary sources. The publisher shall not be liable for any loss, actions, claims, proceedings, demand, or costs or damages whatsoever or howsoever caused arising directly or indirectly in connection with or arising out of the use of this material.
} 
1993; World Bank, 1992). And it also had the potential to weaken workers' lifelong dependency on their employers.

More than two decades later, it is possible to evaluate the privatization process and in particular to investigate its distributive consequences. Not surprisingly, the transition to a market system has been only partial. Indeed, there is an emerging private rental housing market due to the increasing labor mobility and rapid economic development. The growth of a new affluent class of entrepreneurs and professionals has also supported an expansion of housing construction for sale at market prices. Yet a considerable (if declining) share of public housing continues to be occupied by renters, and purchasers of public housing have been highly subsidized. This means that there are effectively at least two types of system operating today in China. Sato (2006) describes these as an 'internal' market that has developed from within the welfare system and an 'open' market that is still being created. It is unclear how long the system will continue in this transitional phase, or at what point people will be making housing choices largely in terms of the standard market criteria of price, quality and location.

In the meantime the type of housing that people live in depends not only on their market resources but also - and in fact mostly—on their position in the pre-reform system. Similar to the experience in several other countries, privatization of public housing took the form of transferring ownership to tenants. In the Chinese case this had to be accomplished in an economy where most people had little access to capital, with only the beginning of a system of home mortgages and no recent history of market pricing. Privatization had to be subsidized, while public rental housing continued to be priced below market levels.

This paper examines who were the winners in this particular phase of China's 'marketization' policy. This question is pursued through analysis of Census micro-level data in the year 2000 from eight major cities that include information on types of housing tenure, various measures of quality and cost. Concretely, the paper asks who is paying less for better housing by virtue of state subsidy?

Similar questions have been raised in other countries where public housing underwent privatization. It has been widely reported that the privatization of public housing in Eastern Europe and the Russian Federation after 1990 represented substantial transfers of wealth in the form of giveaways and discounted sales of public housing apartments to sitting tenants. Discounted sales and the free transfer of public housing to sitting tenants are rationalized as enabling strategies that restore housing market demand and increase mobility and housing choice (Angel, 2000). It is also said that the policy is a form of payback for a process of many years when households 'financed capital subsidies for past investment with forced savings through the wage repression mechanism' (Buckley, 1996, p. 40). However, since not all citizens benefit from the privatization policy, it is essential to evaluate more carefully the distributional impacts.

Kosareva \& Struyk (1993, p. 97) note that evidently 'housing privatization potentially involves an enormous transfer of wealth to individual households'. In major Russian cities in 1992, for example, they estimated the market value of an average public housing unit at more than six times the average annual family income. To achieve rapid privatization the prices were highly subsidized. For example, in Hungary approximately 35 per cent of the public housing stock existing in 1990 had been privatized by 1993 at prices between 15 per cent and 40 per cent of market value (Hegedüs \& Tosics, 1994). Pickvance (1994, pp. 435436) points out that in Hungary even before privatization of public housing those persons with higher occupational status benefited from both the original socialist system and the expansion of the private housing stock: first by being allocated the most attractive state 
housing, then by cashing in on the value of these apartments by selling occupancy rights to new tenants, and finally by purchasing on favorable terms in the private sector. Kosareva \& Struyk (1993) make a similar evaluation for Russia, that higher-income households occupied the more valuable public housing and (since prices were only modestly adjusted for quality and in any case were much lower than market valuation) therefore received larger transfers of wealth through privatization. Other research suggests that the impacts varied by country. Yemtsov (2007), for example, studies three countries, Russia, Serbia and Poland. His findings suggest that public housing privatization strongly increased wealth inequality in Russia and Serbia, but resulted in less wealth inequality in Poland. Yemtsov argues that the impact of privatization depends on two factors at the national level-the size of the privatized stock and the policies that countries put in place to promote homeownership.

Cheap prices do not necessarily make a good investment. The actual value of public housing depends in large part on the quality of initial construction and need for repair. In Britain, for example, sometimes the better units were sold and the low-quality units had no takers. In other cases low-income families, lured by the prospect of homeownership, took on loan burdens that they could not sustain, or they were unable to keep their homes in good repair (Karn \& Wolman, 1992). The other side of this question is that many people remain in public rental housing, and it is necessary to ask what is the quality and rental rate for that housing. Again in the British case, it has been argued that local authority housing was 'worth' considerably more than the remaining tenants were paying in rent (Willis \& Nicholson, 1991), so those who continued to rent in this sector certainly did better than those who rented in the private sector.

Therefore, in order to evaluate who came out ahead in housing privatization in China, it is necessary to determine what is being paid and what a comparable unit would cost in the private sector. For those who purchase public housing, this is the difference between their purchase price and the prices paid for those who bought private market housing. For those who continue to rent in the public sector, it is the difference between their rents (adjusted for quality) and rents paid by people in the private market.

\section{The Chinese Case}

In comparison to Eastern Europe, where the overall share of state-owned housing at the end of the socialist period was only 28 per cent (Hegedüs \& Tosics, 1996), public housing in China was absolutely dominant in urban areas before the reform. Huang (2004) reports that 75 per cent of households were in the public rental housing sector through the socialist period, and the share might be even bigger in large cities (Logan et al., 1999). Because rents were set at extremely low levels (less than 1 per cent of household income according to Wang \& Murie (1999)), public housing was heavily subsidized, and one motivation for housing reform was to reduce the burden on municipal and work unit budgets (Yang \& Wang, 1995). Housing reform began in 1988 with rent reform, increasing rent to reflect real housing costs. At the same time, a wage adjustment was mandated to provide offsetting compensation to workers. In no case was rent raised more than the cash subsidy. This policy reinforced inequalities between work units without redistributing housing: since rich units can provide more subsidies, they recapture most wage adjustment (World Bank, 1992). The rent increase was later followed by a plan to shift public housing to private ownership and to promote development of market housing. As of 2000, the share of public rental housing nationally was 16.33 per cent, and in Beijing it was 33.82 per cent (Logan et al., 2009), and it has been declining since that time.

A key question for China's policy makers was how to price the sale of public housing. Their approach was to set a standard price of construction in each city, based on floor space, and 
to adjust it according to characteristics of the location, the building and the housing unit itself. The discount rate was also adjusted according to characteristics of the purchaser. To illustrate these rules, the paper here describes the pricing formula that was applied to housing controlled by central government institutions in Beijing (for details, see http:// www.ggj.gov.cn/zcfg/zfzdgg/200510/t20051020_2042.htm). The most significant locational factor in that scheme was an assessment of land values in the neighborhood, which could vary the price by as much as 30 per cent. Access to shopping, availability of public transportation and other public infrastructure were also taken into account. A building factor adjustment considered such features as the age of the structure (buildings more than 30 years old, for example, were discounted by 30 per cent), building materials, elevators and height. Unit characteristics included which floor the apartment was on (favoring the highest floors in buildings with elevators, and floors 3-4 in buildings without elevators) and the direction faced by bedroom windows (with a 3 per cent discount for west-facing bedrooms).

The amount of subsidy provided under the Beijing Government housing regulations also depended on the employee's job rank. This is routine in China, where since the mid-1950s government regulations have established official standards for housing space that institutionalized cadre privilege (Zhou \& Logan, 1996). For the lowest level administrative position ( $K e$ and below), for example, employees were considered qualified for an apartment of $60 \mathrm{~m}^{2}$. This meant that the tenant would receive a subsidized price on the first $60 \mathrm{~m}^{2}$, but would pay the standard price for additional space. A $J u$ level official, in contrast, qualified for a subsidy on up to $120 \mathrm{~m}^{2}$.

There is considerable variation in how different work units applied rules such as these. The 'standard price' (not a market price) often depended on seniority. Beginning in the 1990s the state introduced a mandatory Housing Provident Fund to which employees were required to contribute a fraction (around 5 per cent) of their salary, matched by the employer, for the purpose of financing a housing purchase (Yeung \& Howes, 2006). Employers are required to set up this savings account for employees, and the money in this account can only be withdrawn when the employee buys a house or retires. An additional subsidy provided by many work units is based on the number of years that the person was working prior to establishment of the Housing Provident Fund (and if the spouse was in the same work unit, those years would also be counted). In addition, work units that owned or controlled housing were free to offer different prices for different tenants. But for those who did not work for a government agency and whose work unit controlled no housing, as well as those who could not qualify for any subsidy (i.e. persons who are not employed, or who do not have a local urban registration), privatization offered no benefits.

As a starting point, the study hypothesizes that if there is a benefit to public housing purchase or remaining a public housing renter (compared to purchase or rental in the private market) the benefit will most likely be distributed in a way that mirrors past practices. Thus it is important to document which workers had been favored in housing allocation in the past. Formally housing was a welfare benefit to be distributed based on merit and need. Yet there is considerable evidence that in China, like other socialist countries (Szelenyi, 1983), individuals of higher socio-economic and political status have had privileged access to housing of good quality and at a low cost. Logan et al. (1999) showed that housing was allocated partly on the basis of seniority through a continuous process over time of negotiating for larger or better-equipped housing. Income, education and Communist Party membership had positive effects on the size and quality of housing, as did employment in a larger and administratively more powerful work unit. Pan (2004) found that Communist Party membership was associated with larger housing size and higher housing quality in both 1988 and 1995. Davis (2003) showed that workers with more seniority in higherranked work units were more likely to receive better housing. 
There is little research on access to housing in the post-1990 period when the marketization policy was greatly expanded. One exception is Sato's (2006) study of prices for housing purchased during 1996-1999. Sato reported that seniority, education, work unit administrative rank and party membership resulted in reduced prices for housing purchased in the public sector. Sato also documented the disadvantages of migrants in the emerging housing market (on this point see also Logan et al., 2009). Most migrant households have to rent or sublet housing owned by urban households, often at very high prices. Rent and utilities amounted to an average of 26 per cent of total household expenditure for migrants, compared to only 7 per cent for locally registered urban households, largely because of migrants' exclusion from public rental housing.

\section{Research Design}

It was expected that similar disparities would be found in the prices paid for housing. This study uses 2000 Census micro-data (a public use sample of 0.1 per cent) to quantify the differences in prices in the public and private sector for both housing purchase and rentals. The Population Census in 2000 provided detailed information on housing for all family households. It identified six modes of housing tenure for these households. These include two rental categories, renting from the public sector (municipalities or work units) and renting in the private market. There are four types of ownership, distinguishing how the home was acquired: self-built housing, purchase of former public rental housing, purchase at market prices, and purchase at discounted ('economic') prices. This paper focuses on the transition of housing tenure from public to market forms, thus the self-built housing group is not included in the analysis. The 2000 Census actually reflects information in 1999, just one year after the official termination of public housing provision. The purchase of public rental housing by sitting tenants has continued since that time, and the analysis does not include those purchases.

This source has the advantage of broad coverage of urban China. It includes residents of eight of the largest cities: Beijing, Chongqing, Guangzhou, Harbin, Nanjing, Shanghai, Tianjin and Xi'an. There are significant regional differences. For example, Huang and Clark (2002) found in a national housing survey that nearly half of total variation in tenure choice is between cities (see also Li \& Wu, 2004). Such differences are acknowledged by the inclusion of city dummy variables in the multivariate models, so that all prices are in effect measured from the city average. Beijing, Tianjin, Shanghai, Nanjing and Guangzhou are major coastal cities, usually considered to have been earlier to introduce market reforms and to experience rapid economic expansion (especially Guangzhou, which is located close to Hong Kong). Chongqing, Xi' an, and Harbin (and to some extent also Tianjin, which was long dominated by state-run industrial enterprises) are regarded as late developers. However, all have populations that would define them as megacities on a world scale.

These data have important limitations. Persons in collective housing (very common for migrants in work unit dormitories) are excluded, for whom expenditures are not reported in the Census, or self-built housing (the usual source for rural villagers) where the building cost is not comparable to other owner-occupied housing. The Census identifies five tenure types that can be compared. In the public sector these are public purchase by sitting tenants and public rentals (which could be from the municipal housing bureau or from the person's work unit, alternatives that cannot be distinguished in the 2000 Census). Public purchase is compared with two tenure categories that are treated as market-based: market purchase (including most housing sold at market prices) and 'economic purchase' (a form of private housing where builders pass on limited construction subsidies to qualifying buyers, including the categories of Jinji shiyong zhufang and Anju gongzheng housing. Because the economic purchase category, which explicitly involves a price subsidy, is included in the 
models, the analyses reflect the overall differences between public purchase and marketbased purchases. The additional subsidy from 'economic purchase' is estimated in the coefficient for that variable in the market purchase model. The date of purchase is not reported, but the study is able to control for whether persons have lived in their current neighborhood for more or less than five years. Because all forms of purchase increased greatly during the late 1990s, it is not thought that rising purchase prices bias this comparison. Current (1999) rents are compared for public and private rental housing. In both the owner and renter sectors all prices are provided by the Census in categories, which are coded to the category midpoint. Values in the top category are coded to the category's minimum value.

Hedonic models (Follain \& Jimenez, 1985; Rosen, 1974) are estimated to determine how purchase prices and rents in the private sector are related to characteristics of the housing unit. In such models it is expected that larger size, higher quality, existence of amenities and better accessibility should all predict a higher housing price. Hedonic models have been applied in studies of the impact of urban green spaces in Guangzhou (Jim \& Chen, 2006) and Jinan (Kong et al., 2007). A pre-condition for the successful application of hedonic pricing is the existence of a mature housing market that is achieving equilibrium. This is of course not the case for China, so the results reported here should be interpreted as a first approximation. The purpose is to apply the hedonic model coefficients to housing units in the public sector, estimating what approximate comparable units would cost if they were in the private market. The difference between this estimated cost (or 'market value') is what will then be treated as the subsidy received by public sector purchasers or tenants.

The models use all available housing characteristics from the Census. Housing space is measured in square meters, and a second-order term is included to test for non-linearity. Housing quality is an index ranging from 0 to 100 based on five equally weighted aspects of housing units: with or without kitchen, energy source for cooking (gas is treated as the favorable type), with or without tap water, bath facilities and individual toilet. Number of rooms (that is, having smaller rooms in a given space) is usually considered to be a negative quality. Building types are categorical variables: low-rise, high-rise and courtyard housing. There are few cases of courtyard housing among market purchasers, so this housing type is excluded from the analysis of owner housing. Building age is the number of years since construction.

Based on these variables and hedonic models for private market housing, the 'market value' of apartments in the public sector and the subsidy received by public sector participants is estimated. In turn, the personal characteristics associated with receiving higher or lower levels of subsidy are analyzed. These models also make use of the limited number of characteristics that are available from the Census.

A key predictor is residence status, which uses three types of information. The first is whether the person was born in the current city of residence (to distinguish migrants from natives). The second adds an institutional status, whether the person has a rural or urban household registration (i.e. agricultural or non-agricultural eligibility). The third is related to length of residence in the city among migrants. A person who was living in the current city before 1995 is treated as an 'established' resident; someone who has arrived within the last five years is 'recent'. Combining these three criteria leads to six categories of residence status: urban natives; rural villagers; established urban migrants; recent urban migrants; established rural migrants; and recent rural migrants. All cases of public purchase have urban and local registration, because there were too few such owners with rural or non-local registration to be studied. 
A related variable is the spouse's registration status, which is combined with marital status into a 'living status' variable with three categories: living with a spouse with urban registration; living with a spouse with rural registration; and living without a spouse. Does the registration status of one spouse compensate for that of the other? In 1998 a reform of the hukou system made it easier for an urbanite's migrant spouse to apply for urban registration. However, the process is not easy, and there remained many households in 2000 where spouses had different types of registration.

Another variable relevant to trends in prices is recent relocation within the city (within the last five years). In this dataset 'moves' are recorded only if the person changes neighborhood (street district). 'Recent movers' are defined as persons who moved across neighborhoods in the past five years.

The socio-economic variables available from the Census include education, spouse's education (for those living with their spouse), and occupation. Education is measured as years of schooling. Occupation is a set of dummy variables ranging from work unit heads and professionals/technicians at the top to agricultural laborers at the bottom, with separate categories for persons who are retired or not employed. Following the precedent of studies of housing tenure in China, the study introduces gender, age (treated as a possible non-linear effect), and household size as demographic control variables.

\section{Results}

Table 1 provides descriptive statistics for the eight-city sample. By a large margin the majority of cases of owner-occupied housing and rental housing are public sector, with slightly more cases of public purchase than continuing public rental. In the period since 2000, not shown here, there has been a more pronounced shift toward public purchase, with some increase in market purchase and private rental. Table 1 shows how the central variables in the analysis (space and quality) vary across different tenure categories, and also the average prices (purchase cost or rent per square meter). Market purchased housing is subdivided into two categories: commodity housing (at full market prices) and economic purchase (at somewhat discounted prices through a limited government program).

Commodity housing tends to be considerably larger than other owner-occupied housing, but not to be of much higher average quality than public purchased housing. Yet on average its price is nearly five times as high per square meter. Public rental housing on average is larger than private rental housing, and is of much higher quality (although lower quality than any category of owner-occupied housing). Its price is less than one-quarter as much per square meter. These price comparisons and the advantage that public sector housing represents to leaseholders and owners are the motivation for this study.

The next step in the analysis is to estimate hedonic models of housing expenditures among owners and renters in market housing. Results are presented in Table 2. The dependent variable is the log of purchase price or monthly rent. For reference, the Table provides the mean values of space, housing quality, number of rooms and building age for both types of housing, and also the mean values of the purchase price or monthly rent for each city. Economic purchase is grouped together with the market purchase housing group to calculate the hedonic coefficient in Beijing, while a dummy variable is added for economic purchase housing. Market purchased housing is larger, higher quality and newer than market rentals. Purchase prices on average are lowest in Xian and Chongqing and highest in Guangzhou, Shanghai and Beijing. Rental prices are lowest in Xi' an, Harbin and Tianjin, and higher in Guangzhou and Beijing. 
The model for private market owners provides a remarkably good prediction with an adjusted explained variance of 0.604. Coefficients are significant and in the expected direction. Space in square meters has a strong positive effect, diminishing somewhat at high values. Housing quality is strongly related to purchase price. High-rise construction is more expensive, but older buildings command lower prices. For a given amount of floor space, apartments divided into more and smaller rooms cost less. The coefficient for 'economic purchase' shows a substantial discount. Prices in Tianjin and Nanjing are not significantly different from Beijing. Guangzhou and Shanghai are considerably more expensive, while Chongqing, Xi' an and Harbin have significantly lower prices.

The model for private market renters is less robust, but still explains 0.338 of the variance in rents. Rents increase linearly with space and quality. High-rise buildings have higher rents than low-rise apartments, while courtyard housing is less expensive. Surprisingly, building age is unrelated to rents, perhaps because building quality and construction type have been controlled. Rents in all other cities are lower than in Beijing, especially in Chongqing, Harbin and Xi' an.

The final step in this analysis is to determine which residents in the public sector live in housing of higher estimated market value and who receives a higher level of subsidy (discount from the market value in the actual purchase price or rent paid). One important missing variable in the private sector models is location, because the Census micro-data offer no geographic detail within cities. When the hedonic equations are applied to estimate the market value of housing in the public sector, results would be overestimated if public purchase and public rental housing tends to be found in worse locations than corresponding private market units. In fact, there is reason to believe that the approach leads to underestimates of the value of public sector housing. Research on land and housing prices generally shows that inner-city locations are more highly valued. For example Zheng \& Kahn (2008) report that land prices and purchase prices for new condominiums in Beijing in 2004-2005 declined at a rate of about 4 per cent per kilometer from the center of the city at Tiananmen Square. Figure 1 shows that in Beijing (mapping aggregated Census data for neighborhoods [jie dao] in 2000) the share of rental units that is public sector housing is much higher in the inner districts than at the periphery of the urban area. The correlation between public rental share and distance from the center of the city (weighting neighborhood areas by the total number of rental units) is -0.48 . Hence public sector rental housing tends to be found in higher value locations. There is a smaller but not significant negative correlation between the share of owner housing that is public purchase (not counting self-built housing) and distance from the center $(-0.16)$. Purchase of work unit housing in factory locations outside the city partly offsets the concentration of public purchase in the inner districts.

Li \& Siu (1997) studied the city of Guangzhou and concluded that in the subsidized sectors, the pricing of the housing units (including both the selling price and the rent charged) is still far from 'rational': prices and rents increase rather than decrease with distance from the city center. It is thought this difference is due to the lower quality of housing in the inner city, which Li \& Siu did not account for.

Table 3 reports the estimated average discount rates for all of the cities. On average the discount on public purchase housing (compared to market purchase housing) was 38 per cent. Discount rates varied across cities, highest in Beijing and Xi' an and lowest in Shanghai. The average discount rate on monthly rent was 28 per cent, with a high of 37 per cent in Guangzhou and a low of 21 per cent in Tianjin. These levels of subsidy are in line with estimates cited above for Hungary in the 1990s. It is also possible to estimate the aggregate value of the subsidies in each city, applying the sample values to the full urban 
population. There is a substantial redistribution of wealth, nearly $\$ 30$ billion for the public housing that had been purchased by tenants up to 1999 and more than \$9 billion in Shanghai alone. The annual rent subsidy for those who continued to live in public rental housing was more than $\$ 1.2$ billion. Note from the analysis above that a majority of family households in these cities benefited from these subsidies. Those who are excluded entirely from this analysis are people in collective households, the predominant form of housing for ruralurban migrants; this aspect of marketization only indirectly affected these people.

The paper now turns to the question of which public purchasers and which public renters received the greatest benefit. The results for public sector housing are presented in Tables 4 and 5. In almost every case the purchase price or rent is lower than the estimated market value. It is thought that the exceptions represent situations where the apartment is in a particularly favorable location and the hedonic model underestimates the market value. Hence, in cases with an estimated negative subsidy the discount ratio has been recoded to reflect a subsidy of at least 500 yuan for public purchase and 0.50 yuan per month for public rental. Note that in these models, all variables are characteristics of the head of household or spouse. Characteristics of the housing unit itself are summarized in the estimated market value. The city of residence is included here, because housing policies vary across urban China and it has been shown that the discount ratio also varied.

Table 4 provides results for persons who purchased their public housing apartment. The estimated market value of their apartment is highest in Guangzhou and Shanghai and lowest in Chongqing, Harbin and Xi' an. Older household heads and those with larger households live in more valuable apartments. The education of both the household head and spouse has significant positive effects. Not surprisingly, persons who are the head of their work unit own the most valuable housing, followed by staff workers (cadres). Manual workers and retired/unemployed persons live in the least valuable homes. Residence status has a substantial effect. Note that this analysis includes no persons with rural or non-local registration. However, compared to a native person with urban and local registration, recent migrants with similar registration purchased more valuable apartments, as did established migrants to a lesser degree. Persons living without a spouse own more valuable apartments than persons married to a spouse with urban registration, but those whose spouse has a rural registration own significantly less valuable homes. Finally, recent movers within the city (those who changed neighborhoods in the last five years) live in substantially more valuable homes, which may partially reflect recent construction.

These results are consistent with expectations about who could afford a better apartment or who had been living in a better public rental apartment and was therefore in a position to purchase it. A separate question is how large a subsidy they received when they purchased. This discount ratio is analyzed in the second column of Table 4 . Here it can be seen that the discount ratio was higher in every other city than in Beijing, with the exception of Xi' an. The highest subsidies were in Shanghai, Tianjin and Nanjing. Older persons received a higher subsidy (a non-linear effect that may be related to seniority). Few other variables are significant. There are significant positive effects of higher education and being retired (possibly associated with age and seniority). Recent migrants received a smaller subsidy, as did those who moved more recently within the city.

Patterns are somewhat different among public housing tenants (Table 5). City effects show that tenants in Beijing occupy the most valuable housing, with the lowest values in Chongqing and Xi'an. Male heads of households rent less valuable apartments, while older persons and larger households rent more valuable apartments. Education (both for head of household and spouse) and high ranked occupation (work unit heads, administrative staff and professionals/technicians) are positively related to estimated rental value. In the public 
rental sector some are found to have rural registration. Compared to urban natives, the recent migrants with urban registration live in more valuable apartments, while those of established rural migrants are less valuable. Unexpectedly, there is a positive coefficient for recent rural migrants, and having a spouse with rural registration does not affect rental value. Persons living without a spouse occupy more valuable rentals. Finally, recent movers within the city rent more valuable apartments.

Why do recent rural migrants live in more valuable public rental housing than do urban natives? A starting point is the observation that recent rural migrants are unlikely to have access to public rentals because under usual circumstances they do not qualify. In some cases, however, migrants are offered work unit housing tied to their job. Recent migrants in public rental housing, whether with urban or rural registration, tend to live in newer units, which tend to be built to a higher standard,

Yet recent rural migrants have a disadvantage relative to urban natives in the price they pay. Residence status counts heavily in predicting the discount ratio for public rentals. Compared to urban natives, all other categories of persons receive smaller rent subsidy, although the gap for established urban migrants is small. Recent rural migrants receive the least subsidy. Persons married to a spouse with rural registration also receive smaller subsidy, as do recent movers.

It was also found that men receive a smaller discount from estimated market value than women, while older persons receive higher discounts. Subsidy of public housing rents is highest in Nanjing and lowest in Chongqing. Although higher education and occupation are associated with living in more valuable apartments, they are not related to the level of subsidy. It is suspected (although the information to test this explanation is not available) that workers with higher education and occupation levels are more likely to be employed in higher ranked work units, which historically have been able to provide higher quality housing for their employees. In that case, their access to better housing would be based not on their individual privilege but on the standing of their employer.

\section{Discussion and Conclusion}

For potential beneficiaries the opportunity to take advantage of these deals is time-limited. Comparing tabulations from Census 2000 with data that have been made available from the 2005 mini-Census, the study found that the share of rental housing that is in the public sector declined from over 70 per cent to under 40 per cent in just five years. By 2005 only 8 per cent of urban housing units were public rentals, leaving few tenants with prospects for purchasing their unit. At the same time the share of market housing purchased with no discount nearly doubled, and it seems clear that most newly constructed owner-occupied housing in the future will be in the private sector. Hence in a period of about 20 years, starting slowly around 1990 and now nearly complete, China has achieved its intended restructuring of the urban housing system.

It has been found, consistent with most results elsewhere and the expectations of Chinese urban researchers (e.g. Chen, 1996), that this policy has brought a windfall to those who could take advantage of it. It was also found that those who have been able to remain in public rental housing for the time being receive better accommodation at lower rents than people who rent in the private sector. What were the distributional impacts of these benefits?

If the question were simply who could purchase public housing the answer would be selfevident-it would be those who had been able to qualify for public rental housing (or better quality housing) under the previous system. This is why, for example, in Table 3 there are no cases of rural migrants. They had been largely excluded from public housing in the 
socialist period and even those rural migrants who received public rental housing were not eligible to buy it. The analysis mainly addresses a second-level question: among those who qualified to purchase their public housing unit, and among those who continued to rent public housing in 2000, who got the best housing and who received the most favorable terms?

The allocation of the best non-market housing in 2000 (estimated in terms of its market worth) closely matches the priorities for allocation of apartments under socialism, and here patterns are similar for public purchase and public rental. One criterion of need stands out: household size. Persons who were better placed in their work unit (older persons with more seniority, those with higher education, work unit leaders and administrative staff or professional/technical workers) were favored. Migrants and persons with rural registration did worse, as did those whose spouse had rural registration. It may seem surprising that there is one category of migrants who fared well. These are migrants with urban registration, people whom some scholars have called 'permanent migrants' (Wu, 2002). The Chinese term is qianyi (permanently migrated), different from zanzhu (temporarily settled). Persons can gain entitlement to this change if they are recruited by a state-owned enterprise or by enrollment in an institution of higher education, thereby gaining full legal access to all city public resources. Urban migrants have done better in the urban housing system than natives with urban registration.

It is anticipated that studies using other data sources would show that other privileged groups in the socialist housing system also have been able to obtain more valuable housing. These would be especially members of the Communist Party and employees of larger and more highly ranked work units. These hypotheses cannot be tested with Census data.

Although previously favored groups obtained the best housing in the public sector, they did not necessarily get it with a higher discount from its market value. In both the public purchase and public rental models, older persons receive greater benefit. Education counts in the purchase model but not for rentals. No occupational differences are found in the rental model, and for purchase it turns out to be retired people rather than work unit heads, staff, or professionals/technicians who got a higher subsidy. This means that in many respects the pricing of public sector housing did not redistribute resources. Indeed, it could be argued that aside from the cumulative prior advantages of some groups under socialism the privatization process was carried out in an equitable way. Possibly the application of bureaucratic criteria such as those described above for government-controlled housing in Beijing generally succeeded in translating housing characteristics into prices. Note, however, that the absolute value of privileged persons' discount might be higher, simply because they already occupied better located, larger flats, and price inflation after 2000 probably accentuated differences in the absolute value of the purchase subsidy.

There is, nevertheless, one dimension of state policy that factors heavily into housing outcomes, and that is residence status. Among purchasers of public housing, there are no rural villagers or rural migrants. Recent urban migrants and recent movers received smaller discounts in purchasing public housing. Rural villagers, rural migrants, and persons whose spouse has rural registration are substantially disadvantaged in the pricing of public rental housing. It is not migrant status in itself that matters, since migrants with urban registration may even have some advantages. The continuing state policy to distinguish between urban and rural registration has placed citizens with the latter status at a severe disadvantage in the process of housing reform. In this respect the findings reinforce other studies that focus particularly on the rural-urban divide in Chinese social policy. 


\section{References}

Angel, S. Housing Policy Matters: A Global Analysis. Oxford and New York: Oxford University Press; 2000.

Buckley, RM. Housing Finance in Developing Countries. New York: St Martin's Press; 1996.

Chen A. China's urban housing reform: Price-rent ratio and market equilibrium. Urban Studies. 1996; 33:1077-1092.

Davis, D. From welfare benefit to capitalized asset: the re-commodification of residential space in urban china. In: Forrest, R.; Lee, J., editors. Housing and Social Change: East-West Perspectives. London and New York: Routledge; 2003. p. 183-198.

Follain JR, Jimenez E. Estimating the demand for housing characteristics — a survey and critique. Regional Science and Urban Economics. 1985; 15:77-107.

Hegedüs J, Tosics I. Privatisation and rehabilitation in the Budapest inner districts. Housing Studies. 1994; 9:39-55.

Hegedüs, J.; Tosics, I. Urban Institute \& Metropolitan Research Institute (Budapest Hungary). Washington DC: Urban Institute; 1996. Transition of the Housing Sector in the Central-East European Countries.

Huang YQ. The road to homeownership: a longitudinal analysis of tenure transition in urban china (1949-94). International Journal of Urban and Regional Research. 2004; 28:774-795.

Huang YQ, Clark WAV. Housing tenure choice in transitional urban China: a multilevel analysis. Urban Studies. 2002; 39:7-32.

Jim CY, Chen WY. Impacts of urban environmental elements on residential housing prices in Guangzhou (China). Landscape and Urban Planning. 2006; 78:422-434.

Karn, VA.; Wolman, H. Comparing Housing Systems: Housing Performance and Housing Policy in the United States and Britain. Oxford and New York: Clarendon Press and Oxford University Press; 1992.

Kong FH, Yin HW, Nakagoshi N. Using GIS and landscape metrics in the hedonic price modeling of the amenity value of urban green space: a case study in Jinan City, China. Landscape and Urban Planning. 2007; 79:240-252.

Kosareva N, Struyk R. Housing privatization in the Russian Federation. Housing Policy Debate. 1993; 4:81-100.

Li SM, Wu FL. Contextualizing residential mobility and housing choice: evidence from urban China. Environment and Planning A. 2004; 36:1-6.

Li, S.; Siu, YM. Commodity housing in Guangzhou: An analysis of spatial development patterns and price and rent distributions; Paper presented at the Contemporary China's economic reform and social development studies; 1997.

Logan JR, Bian YJ, Bian FQ. Housing inequality in urban China in the 1990s. International Journal of Urban and Regional Research. 1999; 23:7-25.

Logan JR, Fang YP, Zhang ZX. Access to housing in Urban China. International Journal of Urban and Regional Research. 2009 forthcoming.

Pan Z. Housing quality of Communist Party members in urban China: a comparative study. Housing Studies. 2004; 19:193-205.

Pickvance CG. Housing privatization and housing protest in the transition from state socialism: a comparative study of Budapest and Moscow. International Journal of Urban \& Regional Research. 1994; 18:433-450.

Rosen S. Hedonic prices and implicit markets—product differentiation in pure competition. J.P.E. 1974; 82:34-55.

Sato H. Housing inequality and housing poverty in urban China in the late 1990s. China Economic Review. 2006; 17:37-50.

Szelenyi, I. Urban Inequalities Under State Socialism. New York: Oxford University Press; 1983.

Wang, Y.; Murie, A. Housing Policy and Practice in China. New York: Macmillan Press; 1999. 
Willis KG, Nicholson M. Costs and benefits of housing subsidies to tenants from voluntary and involuntary rent control-a comparison between tenures and income groups. Applied Economics. 1991; 23:1103-1115.

World Bank. A World Bank Country Study. Washington DC: World Bank; 1992. China: Implementation Options for Urban Housing Reform.

Wu W. Migrant housing in urban China—choices and constraints. Urban Affairs Review. 2002; 38:90-119.

Yang, L.; Wang, Y. Housing Reform: Theory Rethinking and Reality Selection [Zhufang Gaige: Lilun de Fansi yu Xianshi de Xuanze]. Tianjin: Tianjin People's Press; 1995.

Yemtsov, R. Housing privatization and household wealth in transition. Research Paper No. 2007/02. Helsinki: United Nations University, World Institute for Development Economics Research; 2007.

Yeung SCW, Howes R. The role of the Housing Provident Fund in financing affordable housing development in China. Habitat International. 2006; 30:343-356.

Zheng S, Kahn ME. Land and residential property markets in a booming economy: New evidence from Beijing. Journal of Urban Economics. 2008; 63:743-757.

Zhou M, Logan JK. Market transition and the commodification of housing in urban China. International Journal of Urban and Regional Research. 1996; 20:400-421. 




Figure 1.

Per cent of rental housing in the public rental sector, Beijing urban neighborhoods in 2000 (four inner city districts outlined in white). Source: 2000 Census files (jie dao data) provided by Department of Geography, Peking University. 
Table 1

Average size, quality and cost of housing by tenure, eight-city sample

\begin{tabular}{lrccl}
\hline & $\mathbf{N}$ & Per capita space $\left(\mathbf{m}^{2}\right)$ & Quality index & Cost per square meter \\
\hline Purchase: & & & & \\
Market & 1177 & 33.2 & 90.2 & $\$ 252.66$ \\
Economic & 722 & 24.9 & 85.6 & $\$ 107.13$ \\
Public & 4594 & 23.6 & 89.5 & $\$ 53.14$ \\
Rental: & & & & \\
Market & 1061 & 14.2 & 58.0 & $\$ 1.39 /$ month \\
Public & 4303 & 17.3 & 72.3 & $\$ 0.30 /$ month \\
\hline
\end{tabular}

Note: Exchange rate 1999: 1 dollar = 8.28 RMB. 
Table 2

Hedonic model of housing expenditure among market owners and market renters

\begin{tabular}{|c|c|c|c|c|}
\hline & \multicolumn{2}{|c|}{ Market owners } & \multicolumn{2}{|c|}{ Market renters } \\
\hline & Mean & Coefficient & Mean & Coefficient \\
\hline Constant & & $2.666^{* *}$ & & $5.065^{* *}$ \\
\hline Area space $\left(\mathrm{m}^{2}\right)$ & 76.13 & $0.030^{* *}$ & 28.58 & $0.011^{* *}$ \\
\hline Square of area space & & $-7.04 \mathrm{E}-5^{* *}$ & & $-1.63 \mathrm{E}-05$ \\
\hline Housing quality index & 90.23 & $0.007^{* *}$ & 58.33 & $0.006^{* *}$ \\
\hline \multicolumn{5}{|c|}{ Building type (Reference: Apartment) } \\
\hline High-rise & & $0.215^{* *}$ & & $0.377^{* *}$ \\
\hline Courtyard & & - & & $-0.294^{* *}$ \\
\hline Number of rooms & 2.18 & $-0.153^{* *}$ & 1.33 & -0.023 \\
\hline Building age (years old) & 6.39 & $-0.037^{* *}$ & 13.49 & -0.001 \\
\hline Economic purchase & $\$ 7338$ & $-0.647^{* *}$ & & - \\
\hline City (Reference: Beijing) & $\$ 17,766$ & & $\$ 36.8$ & \\
\hline Chongqing & $\$ 7391$ & $-0.871^{* *}$ & $\$ 23.5$ & $-1.000^{* *}$ \\
\hline Guangzhou & $\$ 23,853$ & $0.226^{* * *}$ & $\$ 48.6$ & $-0.194^{*}$ \\
\hline Harbin & $\$ 10,833$ & $-0.289^{* *}$ & $\$ 24.4$ & $-0.743^{* *}$ \\
\hline Nanjing & $\$ 14,396$ & -0.029 & $\$ 26.4$ & $-0.434^{* *}$ \\
\hline Shanghai & $\$ 22,210$ & $0.387^{* *}$ & $\$ 24.1$ & $-0.445^{* *}$ \\
\hline Tianjin & $\$ 15,495$ & 0.054 & $\$ 20.8$ & $-0.564^{* *}$ \\
\hline Xian & $\$ 6727$ & $-0.487^{* *}$ & $\$ 19.8$ & $-0.766^{* *}$ \\
\hline $\mathrm{N}$ & & 1751 & & 1029 \\
\hline Degree of freedom & & 14 & & 14 \\
\hline Adjusted $\mathrm{r}$ square & & 0.604 & & 0.338 \\
\hline
\end{tabular}

Notes:

* $p<0.05$

*** $p<0.01$

Cost for renters is cost per month; Exchange rate 1999: 1 dollar $=8.28 \mathrm{RMB}$. 


\section{Table 3}

Average discounts and estimated total subsidy for public housing

\begin{tabular}{|c|c|c|c|c|}
\hline & \multicolumn{2}{|c|}{ Public purchase housing } & \multicolumn{2}{|c|}{ Public rental housing } \\
\hline & Mean discount & $\begin{array}{r}\text { Estimated total } \\
\text { subsidy (millions) }\end{array}$ & Mean discount & $\begin{array}{l}\text { Estimated annual } \\
\text { subsidy (millions) }\end{array}$ \\
\hline Beijing & 0.52 & $\$ 5289$ & 0.24 & $\$ 400$ \\
\hline Chongqing & 0.48 & $\$ 813$ & 0.35 & $\$ 43$ \\
\hline Guangzhou & 0.35 & $\$ 4366$ & 0.37 & $\$ 79$ \\
\hline Harbin & 0.40 & $\$ 1500$ & 0.32 & $\$ 55$ \\
\hline Nanjing & 0.29 & $\$ 2303$ & 0.23 & $\$ 78$ \\
\hline Shanghai & 0.25 & $\$ 9279$ & 0.30 & $\$ 305$ \\
\hline Tianjin & 0.31 & $\$ 2030$ & 0.21 & $\$ 196$ \\
\hline Xi'an & 0.52 & $\$ 849$ & 0.31 & $\$ 23$ \\
\hline Total & 0.38 & $\$ 28,700$ & 0.28 & $\$ 1247$ \\
\hline
\end{tabular}

Notes: Exchange rate 1999: 1 dollar $=8.28$ RMB. 


\section{Table 4}

Regression on estimated market value of public purchase housing and the ratio of the discount represented by the actual price paid

\begin{tabular}{|c|c|c|}
\hline & Housing market value & Discount ratio \\
\hline Constant & $3.178^{* *}$ & $0.112 *$ \\
\hline \multicolumn{3}{|l|}{ City (Reference: Beijing) } \\
\hline Chongqing & $-0.831^{* *}$ & $0.037^{* *}$ \\
\hline Guangzhou & $0.282^{* *}$ & $0.186^{* *}$ \\
\hline Harbin & $-0.489^{* *}$ & $0.160^{* *}$ \\
\hline Nanjing & $-0.083^{*}$ & $0.234^{* *}$ \\
\hline Shanghai & $0.170^{* *}$ & $0.270^{* *}$ \\
\hline Tianjin & -0.024 & $0.220^{* *}$ \\
\hline Xi'an & $-0.542^{* *}$ & -0.003 \\
\hline Male or female (Reference: male) & 0.015 & 0.013 \\
\hline Household head age & $0.011^{*}$ & $0.011^{* *}$ \\
\hline Age squared & $-8.02 \mathrm{E}-05$ & $-7.98 \mathrm{E}-005^{* *}$ \\
\hline Household size & $0.036^{* *}$ & -0.002 \\
\hline Years of education & $0.022^{* *}$ & $0.003^{*}$ \\
\hline Spouse years of education & $0.013^{* *}$ & -0.001 \\
\hline \multicolumn{3}{|c|}{ Occupation (Reference: manual worker) } \\
\hline Head of work unit & $0.228^{* *}$ & 0.013 \\
\hline Professional/technician & $0.068^{*}$ & 0.011 \\
\hline Staff or other personnel & $0.180^{* *}$ & 0.007 \\
\hline Commercial or services & $0.098^{* *}$ & 0.008 \\
\hline Retired & -0.006 & $0.032^{*}$ \\
\hline Other unemployed & 0.019 & 0.014 \\
\hline \multicolumn{3}{|l|}{ Residence status } \\
\hline \multicolumn{3}{|l|}{ Reference: urban native } \\
\hline Established urban migrant & $0.047^{*}$ & -0.007 \\
\hline Recent urban migrant & $0.532^{* * *}$ & $-0.104^{* *}$ \\
\hline \multicolumn{3}{|c|}{ Living status (Reference: living with urban registration spouse) } \\
\hline No spouse & $0.101^{*}$ & -0.031 \\
\hline With rural registration spouse & $-0.238^{* * *}$ & 0.013 \\
\hline Recent within city move & $0.508^{* *}$ & $-0.048^{* *}$ \\
\hline $\mathrm{N}$ & 4357 & 4357 \\
\hline Degree of freedom & 24 & 24 \\
\hline Adjusted $\mathrm{r}$ squared & 0.402 & 0.241 \\
\hline
\end{tabular}

Notes:

Hous Stud. Author manuscript; available in PMC 2013 October 23. 


$$
\begin{aligned}
* & <0.05 \\
* * & <<0.01
\end{aligned}
$$

Dependent variable for the first model is $\ln$ (predicted market value of public purchase housing). Dependent variable for the second model is (1(actual cost of public purchase housing)/(predicted market value)). 


\section{Table 5}

Regression on estimated market rental value of public rental housing and the ratio of the discount represented by the actual rent paid

\begin{tabular}{|c|c|c|}
\hline & Market rental value & Discount ratio \\
\hline (Constant) & $5.015^{* *}$ & $0.765^{* *}$ \\
\hline \multicolumn{3}{|l|}{ City (reference: Beijing) } \\
\hline Chongqing & $-0.879^{* *}$ & $-0.099^{* *}$ \\
\hline Guangzhou & -0.047 & $-0.074^{* *}$ \\
\hline Harbin & $-0.422^{* *}$ & $-0.056^{* *}$ \\
\hline Nanjing & $-0.236^{* *}$ & $0.030^{*}$ \\
\hline Shanghai & $-0.383^{* *}$ & $-0.044^{* *}$ \\
\hline Tianjin & $-0.446^{* *}$ & 0.015 \\
\hline Xi'an & $-0.837^{* *}$ & $-0.074^{* *}$ \\
\hline Male or female (Reference: male) & $-0.041^{*}$ & $-0.015^{*}$ \\
\hline Household head age & $0.011^{* *}$ & $0.004^{* *}$ \\
\hline Age square & $-8.81 \mathrm{E}-005^{* *}$ & $-3.87 \mathrm{E}-005^{* *}$ \\
\hline Household size & $0.050^{* *}$ & -0.005 \\
\hline Years of education & $0.015^{* *}$ & -0.001 \\
\hline Spouse years of education & $0.008^{* *}$ & -0.002 \\
\hline \multicolumn{3}{|c|}{ Occupation (Reference: manual worker) } \\
\hline Head of work unit & $0.213^{* *}$ & -0.033 \\
\hline Professional/technician & $0.086^{* *}$ & 0.018 \\
\hline Staff or other personnel & $0.070^{*}$ & -0.008 \\
\hline Commercial or services & 0.031 & $-0.021^{*}$ \\
\hline Retired & 0.003 & 0.001 \\
\hline Other unemployed & 0.025 & 0.013 \\
\hline \multicolumn{3}{|c|}{ Residence status (Reference: urban natives) } \\
\hline Rural villagers & 0.091 & $-0.344^{* *}$ \\
\hline Established urban migrants & 0.026 & -0.013 \\
\hline Recent urban migrants & $0.237^{* *}$ & $-0.183^{* *}$ \\
\hline Established rural migrants & -0.044 & $-0.357^{* *}$ \\
\hline Recent rural migrants & $0.108^{* *}$ & $-0.445^{* *}$ \\
\hline \multicolumn{3}{|c|}{ Living status (Reference: living with urban registration spouse) } \\
\hline Individually & $0.095^{* *}$ & -0.011 \\
\hline With rural registration spouse & -0.029 & $-0.071^{* *}$ \\
\hline Recent within city move & $0.306^{* *}$ & $-0.043^{* *}$ \\
\hline $\mathrm{N}$ & 4239 & 4239 \\
\hline Degree of freedom & 27 & 27 \\
\hline
\end{tabular}


Market rental value Discount ratio

\begin{tabular}{l} 
Adjusted \\
\hline Notes: \\
$*{ }^{*}<0.05$ \\
$* *$ \\
$p<0.01$
\end{tabular}

Dependent variable for the first model is $\ln$ (predicted market value of public rental housing). Dependent variable for the second model is (1(actual public housing rent)/(predicted market value)). 